\title{
ASSESSMENT OF GYPSUM AND LIMESTONE ROCKS FROM FAT'HA FORMATION (M. MIOCENE) FOR MAKING WALLBOARD IN THE MAKHMUR AREA - NORTHERN IRAQ
}

\author{
AMEer HAYder Khalid ${ }^{*}$ and Ali SAlim Al-QASsab ${ }^{*}$ \\ *Dept. of Geology, College of Science, University of Duhok, Kurdistan Region, Iraq \\ *Dept. of General Sciences, College of Basic Education, University of Mosul-Iraq
}

(Received: December 4, 2020; Accepted for Publication: April 6, 2021)

\begin{abstract}
Five samples of gypsum and one sample of limestone were collected from an outcrop in Qara Chugh Anticline. The samples of gypsum were analyzed chemically before and after calcination. The purity of the samples of gypsum and limestone was calculated and the $\left(\mathrm{H}_{2} \mathrm{O}^{+}\right)$content of the calcined samples of gypsum was determined. The physical and mechanical properties of plaster of Paris produced from calcining the samples of gypsum were tested according to the Iraqi and American Standards. A wallboard sample was made using basic materials according to the American Standard. The chemical analyses of the samples of gypsum and plaster of Paris conform to the Iraqi and American Standards. The Fat'ha Formation rocks in the Makhmur area are suitable for making wallboard. The optimum conditions for calcining the studied gypsum rocks to produce plaster of Paris conforming to the standard specifications and suitable for the manufacture of wallboard are $130{ }^{\circ} \mathrm{C}$ for 1 hour.
\end{abstract}

KEYWORDS: Gypsum, Fat'ha Formation, Makhmur Area, Plaster of Paris, Wallboard.

\section{INTRODUCTION}

W allboard (also known as plasterboard, drywall, or gypsum board) is a panel made of gypsum plaster pressed between two thick sheets of paper. It is used for making interior walls, floors, ceilings, and facade construction. Wallboard construction became prevalent as a speedier alternative to traditional lath and plaster (Mehta et al., 2013). Wallboard differs from other panel-type building products, such as plywood, hardboard, and fiberboard due to its non-combustible core and paper facers. When joints and fastener heads are covered with a joint compound system, gypsum wallboard creates a continuous surface suitable for most types of interior decoration (Kubba, 2016).

The use of wallboard in the building is more economical than bricks and cement (Natus, 1990). It is also used in the manufacture of fireresistant doors, furniture, kitchens, and bathrooms due to its high resistance to moisture and fire. The expansion of reconstruction and urban growth in Iraq increases the need to use new building materials that compete with traditional ones in terms of efficiency, low cost, and environmentally friendly. The availability of the numerous geological resources in Iraq encourages their exploitation in the manufacture of such building materials.

Gypsum rocks are widespread in Iraq, especially in the northern regions. Most of them belong to the Fat'ha Formation (Middle Miocene) which is one of the most widespread and economically important formations in Iraq (Buday, 1980). Limestone and gypsum rocks of this formation are used in many industries, such as Portland cement and plaster. It is also used as building and decorative stone.

The current research aims to assess gypsum and limestone rocks from Fat'ha Formation for making wallboards in the Makhmur area Northern Iraq.

\section{GEOLOGY OF THE STUDY AREA}

The study area is located about $60 \mathrm{~km}$ southwest of Erbil city and about $2.5 \mathrm{~km}$ from Makhmur town. Tectonically, it lies within the Hemrin-Makhul Subzone of the Low Folded Zone in the Unstable Shelf according to the tectonic division of Iraq (Buday and Jassim, 1984) (Figure 1). The outcrop from which the samples were collected belongs to the Fat'ha 
Formation at the northeastern limb of Qara Chugh Anticline with coordinates (N 35 46 $\left.30^{\prime \prime}\right)$ and $\left(\mathrm{E} 43^{\circ} 38^{\prime} 00^{\prime \prime}\right)$. This site is known as Makhmur Gypsum Quarry. The lithostratigraphic section of this site consists of white to light grey massive gypsum beds of varying thickness, underlain by a well-bedded recrystallized limestone bed of $3 \mathrm{~m}$ thick and overlain by a limestone bed of $5 \mathrm{~m}$ thick. The total thickness of the gypsum beds in this section is $82 \mathrm{~m}$ (Figure 2). Gypsum rocks were used in this quarry in the

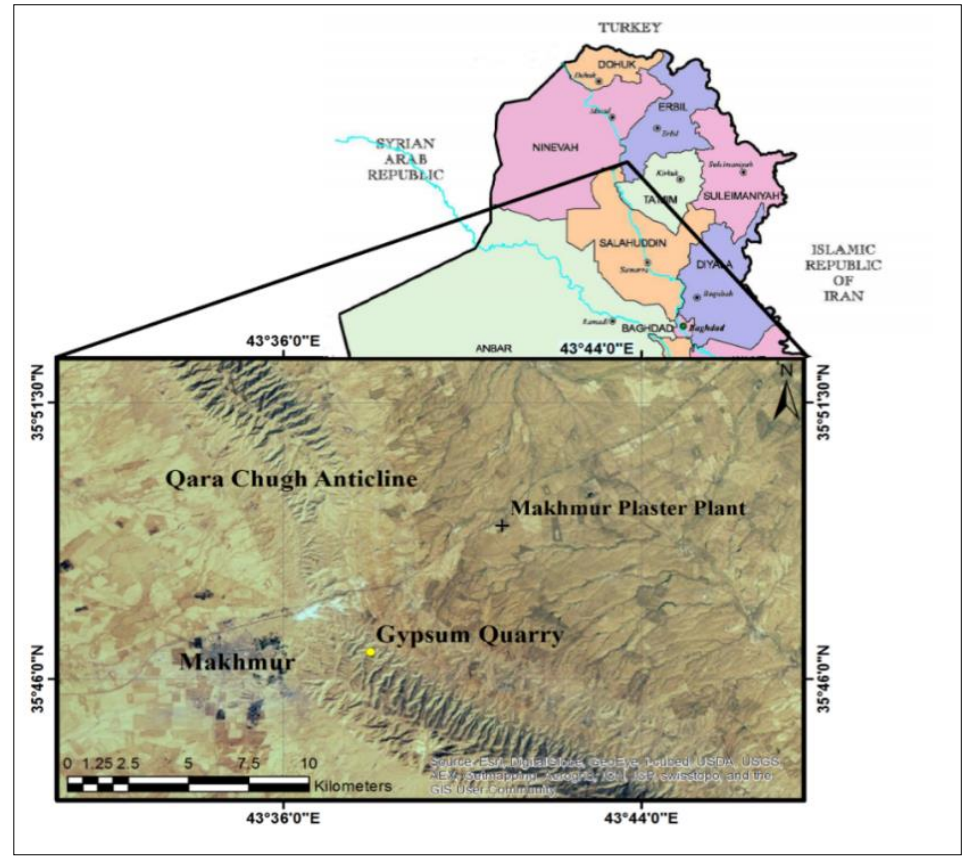

Fig. (1): Location map of the study area. Source: Google Earth. August 24, 2020.

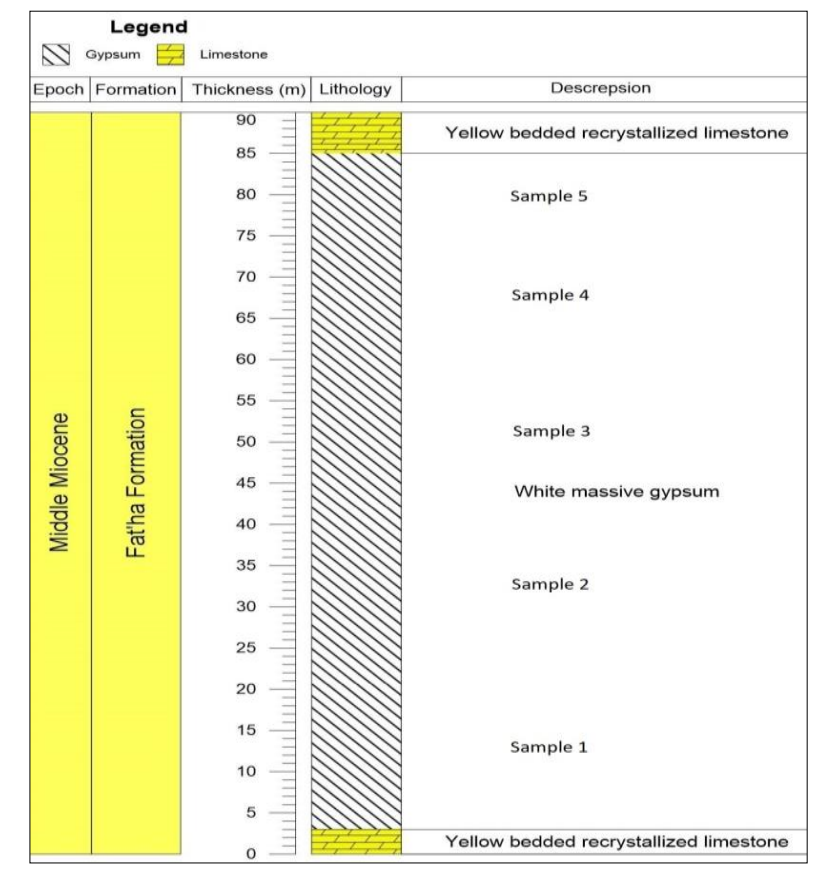

Fig. (2): Lithostratigraphic section of Fat'ha Formation / Makhmur Gypsum Quarry

\section{Fig. (1): Location map of the study area. Source: Google Earth. August 24, 2020.}

production of technical plaster in the Makhmur plant. It is currently used in the manufacture of local plaster calcined by the primitive "Koor" method in several locations near the DibagahMakhmur

road. 


\section{MATERIALS AND METHODS \\ 1. Chemical Analysis:}

Five samples of gypsum and one sample of limestone were collected from the outcrop. The samples of gypsum were washed, dried, and ground by a tema mill. The resulting powders were sieved with a $150 \mu$ sieve and the portion that passed through the sieve was kept in closed boxes for use in chemical analysis. Powders were analyzed chemically before and after calcination. The $(\mathrm{CaO} \%)$ content was measured volumetrically for each powder by titration of calcium oxide $(\mathrm{CaO})$ solution of the unknown sample with $0.01 \mathrm{M}$ EDTA solution using murexide as an indicator. The $\left(\mathrm{SO}_{3} \%\right)$ content was measured gravimetrically by barium chloride $\left(\mathrm{BaCl}_{2}\right)$ to precipitate sulphate ions $\left(\mathrm{SO}_{4}{ }^{2-}\right)$ (Vogel, 1961; Abbawai and Hasan, 1990). The $\left(\mathrm{H}_{2} \mathrm{O}^{+} \%\right)$ content was measured by heating $1 \mathrm{gm}$ of the powder sample in a muffle oven at $400{ }^{\circ} \mathrm{C}$ for 1 hour and calculating the weight loss (Aljubouri, 1972). The insoluble residue (I.R.\%) was measured by dissolving 5 $\mathrm{gm}$ of the powder sample in $10 \mathrm{ml}$ of $10 \% \mathrm{HCl}$ and weighing the residue (Vogel, 1961; Ellingboe and Wilson, 1964). The $(\mathrm{CaO})$ and $\left(\mathrm{SO}_{3}\right)$ contents were measured in the Geochemistry Laboratory, Department of Geology, University of Mosul, while the $\left(\mathrm{H}_{2} \mathrm{O}^{+}\right)$ and (I.R.) were measured in the Analytical Chemistry Laboratory, Department of Chemistry, University of Mosul using the methods described in (Baddy, 2009).

\section{Calcination of Powder Gypsum Samples:}

This process is the most important stage in gypsum processing and wallboard manufacturing, where the gypsum is heated in the form of dihydrate containing water chemically bound by about $21 \%$ of its weight to convert it into plaster of Paris according to the following equation (Venta, 1997):

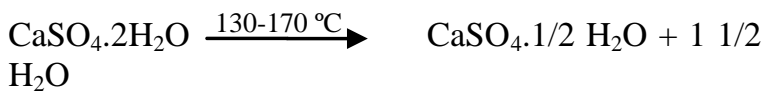

One $\mathrm{kg}$ of each powder was calcined in an electrical oven to produce plaster of Paris according to American Standard (ASTM C28/C28-10, 2015) and (Iraqi Standard No.26, 1969). The calcination method is described in (Al-Qaraghooli, 1989). The limestone sample was analyzed by X-ray fluorescence (XRF) (Model MINI PAL 4 CEMENT extends).

\section{Physical and Mechanical Examinations of Plaster of Paris:}

The compressive strength of plaster of Paris produced from the calcined powders was measured according to the method described in (Aljubouri and Baddy, 2012; Iraqi Standard No.27, 1985) using a compression machine (model ELE HP2 7HB). The (Iraqi Standard No.27, 1985) was followed to measure the water/powder ratio (W/P) and setting time of the plaster of Paris by Vicat Tester (Model No. H3134) and (Model No. H-3050) respectively. The measurement methods are described in (Baddy, 2009; Younis, 2012).

\section{Making a Wallboard Sample:}

American Standard (ASTM C36-C36M, 2004) was followed to make a wallboard sample from plaster of Paris in the laboratory at the Department of Geology, University of Mosul. The main components used are a wooden mold $(10 \times 20 \mathrm{~cm})$ (Figure $3-\mathrm{A})$, an iron wire network $(9.5 \times 19.5 \mathrm{~cm})$, and two pieces of cardboard $(10 \times 20 \mathrm{~cm})$ (Figure $3-\mathrm{B})$.

The plaster forming the core of the wallboard sample was prepared and water was mixed with the plaster at a $(\mathrm{W} / \mathrm{P})$ ratio of $50 \mathrm{ml} / 100 \mathrm{gm}$ (Figure $3-\mathrm{C}$ ). A cardboard sheet (veneer) was laid under the wooden mold and the plaster was mixed with enough water to form a smooth plastic mass. After the mass had completely hardened it was mixed with the limestone powder and an additional amount of water to prepare the gypsum slurry. The limestone powder was added at a rate of $0.1 \%$ to the mixture as a retarder in order to increase the setting time and allow the formation of the plaster mixture for molding and shaping during the preparation of the wallboard sample (Figure 3 - D). The slurry mass was poured to half the thickness of the wooden mold and the iron wire network was laid to increase the hardness of the prepared sample. The second half of the mold was poured with the slurry mass and the second sheet of veneer was laid to cover the wooden mold (Figure $3-$ E). The finished wallboard sample was dried in an electric oven at $35^{\circ} \mathrm{C}$ for 1 hour according to American Standard (ASTM C36-C36M, 2004) (Figure $3-F$ ). 


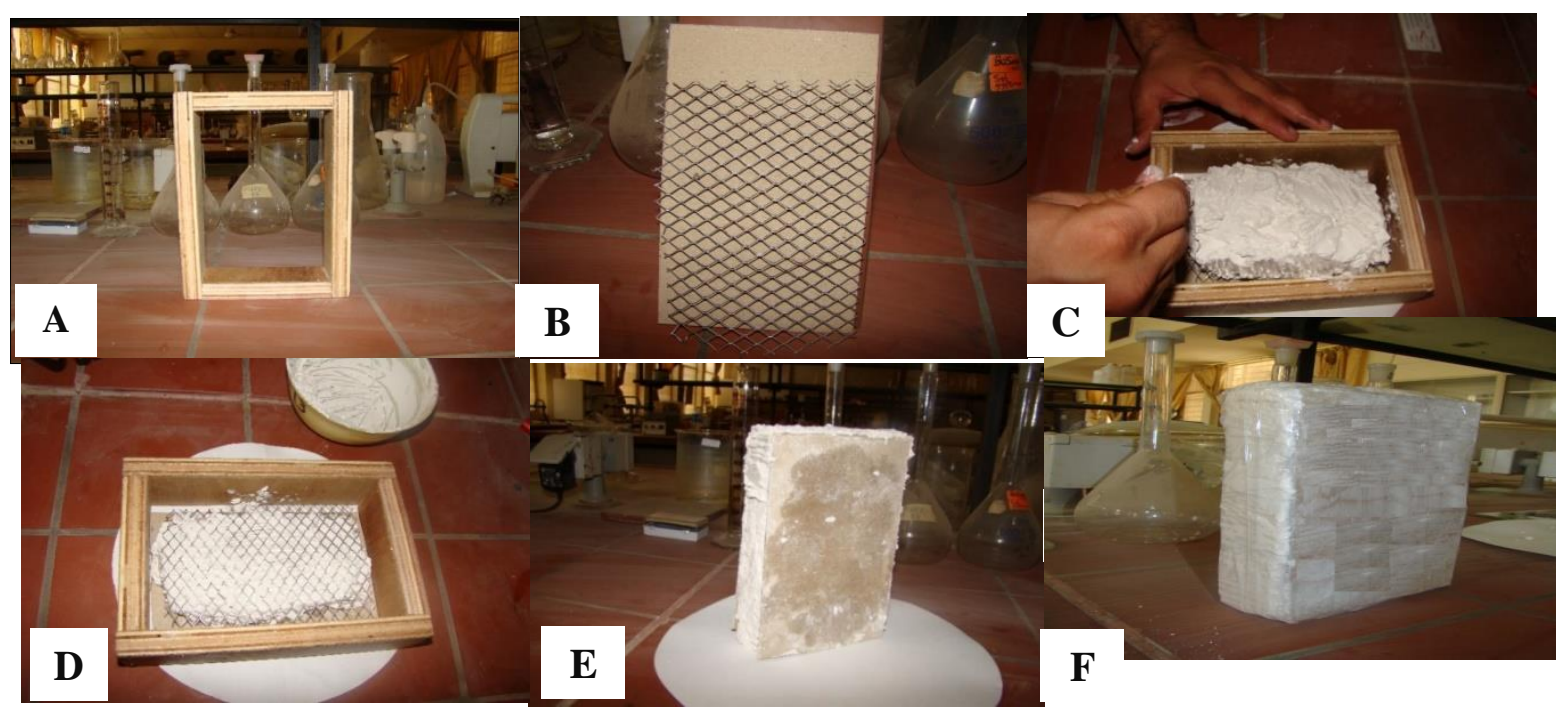

Fig. (3): Making a wallboard sample. A: Wooden wallboard mold; B: Cardboard and iron wire network; C: Mixing the plaster with water; $\quad$ D: Adding the limestone powder to the mixture; $\mathbf{E}$ : The wallboard sample before drying; F: The finished wallboard sample.

\section{RESULTS AND DISCUSSION}

The chemical analysis showed significant differences in the $(\mathrm{CaO} \%)$ and $\left(\mathrm{SO}_{3} \%\right)$ contents (before and after calcination) and there were no significant differences in the $\left(\mathrm{H}_{2} \mathrm{O}^{+} \%\right)$ content and (I.R.\%). The total content of the main gypsum components $\left(\mathrm{CaO}, \mathrm{SO}_{3}\right.$, and $\left.\mathrm{H}_{2} \mathrm{O}\right)$ ranged between $97-98 \%$ of the weight of the gypsum samples. These results are close to the ideal chemical composition of gypsum (32.57\%
$\mathrm{CaO}, 20.93 \% \mathrm{H}_{2} \mathrm{O}$, and $46.50 \% \mathrm{SO}_{3}$ ) and this indicates the high purity of the studied gypsum rocks. The remaining $(2-3 \%)$ represents the other secondary components $\left(\mathrm{Fe}_{2} \mathrm{O}_{3}, \mathrm{Al}_{2} \mathrm{O}_{3}\right.$, and $\mathrm{K}_{2} \mathrm{O}$ ) which reflect a small amount of detrital impurities that were supplied to the sedimentary basin. According to (Aljubouri and Sulayman, 1996), the first component represents the evaporite minerals while the second component represents the detrital minerals.

Table (1): The chemical analysis of gypsum powder samples before and after calcination

\begin{tabular}{|c|c|c|c|c|c|}
\hline Contents & $\mathbf{N}$ & & Mean & SD & P- value \\
\hline $\mathrm{CaO} \%$ & 5 & $\begin{array}{l}\text { Before calcination } \\
\text { After calcination }\end{array}$ & $\begin{array}{l}32.17 \\
37.78\end{array}$ & $\begin{array}{l}1.2386 \\
0.4374\end{array}$ & 0.0393 \\
\hline $\mathrm{SO}_{3} \%$ & 5 & $\begin{array}{l}\text { Before calcination } \\
\text { After calcination }\end{array}$ & $\begin{array}{l}45.71 \\
53.76\end{array}$ & $\begin{array}{l}0.3980 \\
0.1513\end{array}$ & $<0.0000001$ \\
\hline $\mathrm{H}_{2} \mathrm{O}^{+} \%$ & 5 & $\begin{array}{l}\text { Before calcination } \\
\text { After calcination }\end{array}$ & $\begin{array}{c}19.93 \\
5.30\end{array}$ & $\begin{array}{l}0.1449 \\
0.1782\end{array}$ & 0.6609 \\
\hline I.R.\% & 5 & $\begin{array}{l}\text { Before calcination } \\
\text { After calcination }\end{array}$ & $\begin{array}{l}1.56 \\
2.12\end{array}$ & $\begin{array}{l}0.3129 \\
0.2679\end{array}$ & 0.7416 \\
\hline Total & 5 & $\begin{array}{l}\text { Before calcination } \\
\text { After calcination }\end{array}$ & $\begin{array}{l}99.37 \\
98.95\end{array}$ & $\begin{array}{l}1.0105 \\
0.5687\end{array}$ & 0.2327 \\
\hline
\end{tabular}

The purity of gypsum samples was calculated using the following equation (Aljubouri, 1972):

Gypsum $\left(\mathrm{CaSO}_{4} .2 \mathrm{H}_{2} \mathrm{O}\right)(\%)=\mathrm{H}_{2} \mathrm{O}^{+} \% \times$ $4.778=19.93 \times 4.778=95.23 \%$

The purity of gypsum rocks varies widely, ranging from $80-95 \%$. This property is important in the manufacture of wallboard which requires high purity gypsum to produce lightweight wallboard (Henkels and Gaynor, 1995). The physical and mechanical properties of pure gypsum can be easily controlled by adding retarders and accelerators compared to impure gypsum.

The average contents of $(\mathrm{CaO} \%),\left(\mathrm{SO}_{3} \%\right)$, $\left(\mathrm{H}_{2} \mathrm{O}^{+} \%\right)$ and (I.R.\%) for the gypsum samples conform to American Standard (ASTM 
C22/C22M-00, 2015) and (Iraqi Standard No.26, 1969) as well as (Othman, 2002; Mohammed, 2010; Yousif, 2011). The $(\mathrm{CaO} \%),\left(\mathrm{SO}_{3} \%\right)$ and $\left(\mathrm{H}_{2} \mathrm{O}^{+} \%\right)$ contents of plaster of Paris in this study are close to those of American Standard (ASTM C28/C28M-10, 2015) and plaster of Paris produced by (Othman, 2002; Aljubouri and Baddy, 2012; Younis, 2012).

Table (2) shows the results of the average content of plaster of Paris in the current study compared with the commercial plasters in (Aljubouri and Alrawas, 2006) and (Aljubouri and Baddy, 2012) and the theoretical bassanite or hemihydrate $\left(\mathrm{CaSO}_{4} \cdot 1 / 2 \quad \mathrm{H}_{2} \mathrm{O}\right)$. The $\left(\mathrm{CaO} / \mathrm{SO}_{3}\right)$ ratio in the plaster in this study was slightly higher than that of the theoretical bassanite (7.00), indicating a small amount of dolomite in the produced plaster. Gypsum and its products usually contain a small amount of dolomite, which is believed to be a product of local dolomitization (Othman, 2002; Aljubouri and Alrawas, 2006; Baddy, 2009; Mohammed, 2010).

The composition of bassanite $\left(\mathrm{CaSO}_{4} \cdot 1 / 2\right.$ $\mathrm{H}_{2} \mathrm{O}$ ) in (Table 2) was calculated by multiplying $\left(\mathrm{SO}_{3} \%\right)$ by (1.8129). This oxide is used in place of $(\mathrm{CaO})$ because the latter is present in greater amounts in dolomite (Aljubouri and Baddy, 2012). $\left(\mathrm{H}_{2} \mathrm{O}^{+}\right)$content cannot be used because its quality is controlled by calcination. The oxide content of insoluble residue can be calculated according to (Aljubouri and Alkawaz, 2008) using its chemical analysis as follows:

$\mathrm{SiO}_{2}=$ I.R. $\times 0.578$,

$\mathrm{Al}_{2} \mathrm{O}_{3}=$ I.R. $\times 0.1376$

Total $\mathrm{Fe}_{2} \mathrm{O}_{3}=$ I.R. $\times 0.1055$,

Total $\mathrm{MgO}=$ I.R. $\times 0.1789$

Table (2): Average contents of plaster of Paris in the current study compared to the commercial plasters and theoretical bassanite $\left(\mathrm{CaSO}_{4} \cdot 1 / 2 \mathrm{H}_{2} \mathrm{O}\right)$

\begin{tabular}{|c|c|c|c|c|c|c|}
\hline \multirow[t]{2}{*}{ Oxide (\%) } & \multirow[t]{2}{*}{$\begin{array}{l}\text { Current } \\
\text { Study }\end{array}$} & \multicolumn{2}{|c|}{ Aljubouri and Alrawas (2006) } & \multicolumn{2}{|c|}{ Aljubouri and Baddy (2012) } & \multirow[t]{2}{*}{$\begin{array}{c}\text { Theoretical } \\
\text { Bassanite }\end{array}$} \\
\hline & & Ahlia Plaster & Malej Plaster & $\begin{array}{c}\text { Rasheed Local } \\
\text { Plaster }\end{array}$ & $\begin{array}{c}\text { Madae'n Local } \\
\text { Plaster }\end{array}$ & \\
\hline $\mathrm{CaO}$ & 37.78 & 37.62 & 37.84 & 37.44 & 38.26 & 38.64 \\
\hline $\mathrm{SO}_{3}$ & 53.75 & 53.93 & 54.29 & 53.17 & 53.97 & 55.16 \\
\hline $\mathrm{H}_{2} \mathrm{O}^{+} \%$ & 5.30 & 7.20 & 6.70 & 6.45 & 5.46 & 6.20 \\
\hline${ }^{\star} \mathrm{SiO}_{2}$ & 1.22 & 0.50 & 0.45 & 1.26 & 1.10 & --- \\
\hline${ }^{*} \mathrm{Al}_{2} \mathrm{O}_{3}$ & 0.29 & 0.12 & 0.10 & 0.30 & 0.26 & --- \\
\hline${ }^{*}$ Total $\mathrm{Fe}_{2} \mathrm{O}_{3}$ & 0.22 & 0.09 & 0.08 & 0.23 & 0.20 & --- \\
\hline * Total MgO & 0.38 & 0.15 & 0.14 & 0.29 & 0.33 & --- \\
\hline Total & 98.93 & 99.61 & 99.60 & 99.14 & 99.58 & 100.00 \\
\hline $\mathrm{CaO} / \mathrm{SO}_{3}$ & 0.7029 & 0.7017 & 0.700 & 0.7042 & 0.7089 & 0.700 \\
\hline$\# \mathrm{CaSO}_{4} \cdot 1 / 2 \mathrm{H}_{2} \mathrm{O}$ & 97.44 & 97.77 & 98.42 & 96.39 & 97.84 & 100.00 \\
\hline I.R. & 2.11 & 0.86 & 0.77 & 2.18 & 1.89 & 0.00 \\
\hline
\end{tabular}

* Calculated from insoluble residue (I.R.); $\# \mathrm{CaSO}_{4} .1 / 2 \mathrm{H}_{2} \mathrm{O}=\mathrm{SO}_{3} \% \times 1.8129$

Table (3) shows the chemical analysis of the limestone sample, which can be classified as highly pure by its $\mathrm{CaCO}_{3}$ content. This encourages the use of this limestone as a retarder to reduce the setting time of plaster of Paris during the manufacture of wallboard. 
Table (3): The chemical analysis of the limestone sample

\begin{tabular}{ccccccccccc}
\hline Oxide & $\mathrm{SiO}_{2}$ & $\mathrm{Al}_{2} \mathrm{O}_{3}$ & $\mathrm{Fe}_{2} \mathrm{O}_{3}$ & $\mathrm{FeO}$ & $\mathrm{CaO}$ & $\mathrm{MgO}$ & $\mathrm{Na}_{2} \mathrm{O}$ & $\mathrm{K}_{2} \mathrm{O}$ & $\mathrm{SO}_{3}$ & $\mathrm{CaCO}_{3}$ \\
\hline$(\%)$ & 3.33 & 1.91 & 0.89 & 0.80 & 53.50 & 0.32 & 0.39 & 0.18 & 0.62 & 95.23 \\
\hline
\end{tabular}

The calcination experiments of the for 1 hour, giving a value of $\left(\mathrm{H}_{2} \mathrm{O}^{+}=6.40\right.$ powder gypsum samples showed that the \%) similar to that of bassanite $\left(\mathrm{H}_{2} \mathrm{O}^{+}\right.$ optimum calcination conditions are $130{ }^{\circ} \mathrm{C}=6.20 \%$ ) as shown in (Table 4).

Table 4: The $\left(\mathrm{H}_{2} \mathrm{O}^{+} \%\right)$ content of the calcined gypsum samples compared to the theoretical content of bassanite $(6.20 \%)$ using different temperatures with a constant calcination time of 1 hour

\begin{tabular}{ccc}
\hline Sample No. & Temperature $\left({ }^{\circ} \mathbf{C}\right)$ & $\mathbf{H}_{2} \mathbf{O}^{+} \%$ \\
\hline 1 & 110 & 8.9 \\
\hline 2 & 120 & 7.2 \\
\hline 3 & 130 & 6.4 \\
\hline 4 & 140 & 5.8 \\
\hline 5 & 150 & 5.3 \\
\hline
\end{tabular}

Table (5) shows the physical and mechanical tests of plaster of Paris in the present study. These results are consistent with (Iraqi Standard
No.28, 1988) and (American Standard ASTM C472-99, 2014), as well as the results obtained by (Aljubouri and Alrawas, 2009).

Table 5: Physical and mechanical tests of plaster of Paris in the present study compared to the technical plaster in (Aljubouri and Alrawas, 2009), (Iraqi Standard No. 28, 1988) and American Standard ASTM No. C472-99, 2014)

\begin{tabular}{|c|c|c|c|c|}
\hline Property & $\begin{array}{l}\text { Current } \\
\text { study }\end{array}$ & $\begin{array}{c}\text { Technical plaster } \\
\text { in (Aljubouri and Alrawas, } \\
\text { 2009) }\end{array}$ & $\begin{array}{l}\text { Iraqi Standard } \\
\text { No. } 28,1988\end{array}$ & $\begin{array}{c}\text { ASTM No. C472-99, } \\
2014\end{array}$ \\
\hline Compressive strength (MPa) & 18 & 20 & Not less than 3 & Not more than 50 \\
\hline $\begin{array}{c}\text { Water/powder ratio }(\mathrm{W} / \mathrm{P})(\mathrm{ml} / 100 \\
\mathrm{gm})\end{array}$ & 50 & $40-50$ & ------ & ------ \\
\hline Setting time (min.) & 9 & $6-8$ & $8-25$ & $5-15$ \\
\hline $\begin{array}{l}\text { Fineness (particle size) }(\mu), \\
\text { percentage }\end{array}$ & $\begin{array}{l}-250,100 \% \\
+90,98 \%\end{array}$ & $\begin{array}{l}-250,100 \% \\
+90,90 \%\end{array}$ & $\begin{array}{c}100 \% \text { passing } \\
\text { from sieve No. } \\
16(1.18 \mathrm{~mm})\end{array}$ & $-315(\mu),+80(\mu)$ \\
\hline
\end{tabular}

The compressive strength of plaster of Paris in this study is slightly less than that of (Aljubouri and Alrawas, 2009) because the (W/P) ratio of plaster of Paris in this study is higher than that in the other study as the relationship between (W/P) ratio and compressive strength is inverse (Noort, 2002; Abdulla, 2006). The setting time of plaster of Paris in this study is greater than that of (Aljubouri and Alrawas, 2009) as the relationship between this property and the (W/P) ratio is proportional (McCabe, 1985).

\section{CONCLUSIONS}

The following conclusions were drawn from the current study:

1. The results of the chemical analyses of the gypsum samples and plaster of Paris in this study conform to Iraqi and American Standards.

2. The results of the physical and mechanical examinations of the plaster of Paris produced in this study conform to the Iraqi and American Standards.

3. The gypsum rocks of Fat'ha Formation in the Makhmur area are suitable for use in making 
wallboard. The limestone rocks in this area can also be used as a hardening retarder for gypsum plaster in wallboard making.

4. The optimum conditions for calcining the studied gypsum rocks are at a temperature of $130{ }^{\circ} \mathrm{C}$ for 1 hour to obtain plaster of Paris conforming to the standards of manufacturing wallboard.

\section{REFERENCES}

Abbawai, S. A., and Hasan, M. S. (1990). Environmental Practical Engineering - Water Tests. University of Mosul, 296 p.

Abdulla, M. A. (2006). Evaluation of Some Properties of Gypsum Products and Acrylic Resin by the Use of Some Additives and Microwave Technique. Unpublished M.Sc. thesis, College of Dentistry, University of Mosul, $169 \mathrm{p}$.

Aljubouri, Z. A. (1972). Geochemistry, Origin, and Digenesis of Some Triassic Gypsum Deposits and Associated Sediments in East Midland. Unpublished Ph.D. thesis, Univ. of Nottingham, England, 411 p.

Aljubouri, Z. A., and Alkawaz, H. A. (2008). Geochemistry of Marl Sediments within Fat'ha Formation at Selected Locations, Northern Iraq. Iraqi Jour. of Earth Science, 1, 2, 27-46.

Aljubouri, Z. A., and Alrawas, A. M. (2006). The Petrography and Mineralogy of Technical Plaster and Local Juss. Iraqi Journal of Earth Science, 6, 1, 1-11.

Aljubouri, Z. A., and Alrawas, A. M. S. (2009). Physical Properties and Compressive Strength of the Technical Plaster and Local Juss. Iraqi Jour. of Earth Science, 9, 2, 49-58.

Aljubouri, Z. A., and Baddy, I. R. (2012). Mineralogy, Petrography and Chemistry of Two Local Plasters, Iraq. Iraqi National Journal of Earth Science, 12, 2, 1-16.

Aljubouri, Z. A., and Sulayman, M. D. (1996). Mineralogy and Geochemistry of Gypsum Rocks of Al-Fat'ha Formation at West Butma Area, Northern Iraq. Al-Rafidain Sci. Jour., 7, $1,114-128$.

Al-Qaraghooli, N. A. (1989). Mineralogical and Chemical Properties of the Iraqi Gypsum, Modules and Methods of Manufacturing and its Impact on the Quality and the Quality of Plaster and the Resulting Plaster of Paris. Jour. of the Geological Society of Iraq, 22, 2, 154 172.

ASTM C36-C36 M, 2004. Standard Specification for Gypsum Wallboard. American Society for Testing and Materials. $4 \mathrm{p}$.

ASTM C472-99, 2014. Standard Test Methods for Physical Testing of Gypsum, Gypsum Plasters and Gypsum Concrete. American Society for Testing and Materials. 8 p.

ASTM C28/C28M-10, 2015. Standard Specification for Gypsum Plasters. American Society for Testing and Materials. $4 \mathrm{p}$.

ASTM C22/C22M-00, 2015. Standard Specification for Gypsum. American Society for Testing and Materials. 2 p.

Baddy, I. R. (2009). The Effect of Compression and Additives on Physiomechanical Properties of Artistic Gypsum .Unpublished M.Sc. thesis, College of Science, University of Mosul, 244 p.

Buday, T. (1980). Regional Geology of Iraq: Vol.1, Stratigraphy: I. I. M. Kassab and S. Z. Jassim (Eds) GEOSRVY. Min. Invest. Publ. 445 p.

Buday, T. and Jassim, S. Z. (1984). Final Report and the Regional Geological Survey of Iraq. Unpublished Report SOM. Library. Tectonic Framework, Baghdad.

Ellingboe, J. and Wilson, J. A. (1964). A Quantitative Separation of Non - Carbonate Minerals from Carbonate Minerals. Jour. Sed. Petrol., 34, 412 -418 .

Henkels, P. J. and Gaynor, J. C. (1995). Characterizing Synthetic Gypsum for Wallboard Manufacture. Proceedings of the $4^{\text {th }}$ International Conference on FGD and Other Synthetic Gypsum, May 17-18, Toronto, Canada, 569 - 574.

Iraqi Standard Specification No.26, 1969. Chemical Analysis of Gypsum and its Products. Central Organization for Standardization and Quality Control, Ministry of Planning, the Republic of Iraq.

Iraqi Standard Specification No.27, 1985. Setting Time Tests of Gypsum for Building Purposes. Central Organization for Standardization and Quality Control, Ministry of Planning, the Republic of Iraq.

Iraqi Standard Specification No.27, 1985. Physical Examinations of the Types of Gypsum Slurry. Central Organization for Standardization and 
Quality Control, Ministry of Planning, the Republic of Iraq.

Iraqi Standard Specification No.28, 1988. Building Gypsum. Central Organization for Standardization and Quality Control, Ministry of Planning, Republic of Iraq.

Kubba, S. (2016). LEED v4: Practices, Certification, and Accreditation Handbook ( $2^{\text {nd }}$ ed.). Butterworth-Heinemann, $708 \mathrm{p}$.

McCabe, J. F. (1985). Anderson's Applied Dental Materials. $6^{\text {th }}$ edition. Blackwell, London, UK, $178 \mathrm{p}$.

Mehta, M., Scarborough, W. and Armpriest, D. (2013). Building Construction: Principles, Materials, and Systems ( $2^{\text {nd }}$ ed.). Pearson Education, Inc., USA, 952 p.

Mohammed, B. A. (2010). Mineralogy, Petrography and Geochemistry of Gypsum Rocks in Gercus (Middle Eocene) and Fat'ha (Middle Miocene) Formations/Northern Iraq - a Comparative Study. Unpublished M.Sc. thesis, College of Science, University of Mosul, 111 p. (in Arabic with English abstract).

Natus, G. M. (1990). Gypsum Fiber Board Production in Nova Scotia. Proceedings of the $2^{\text {nd }}$ International Conference on InorganicBonded Wood and Fiber Composite Materials, Moscow, ID, October 15 - 17, 85 - 87.

Noort, V. R. (2002). Introduction to Dental Materials $\left(2^{\text {nd }}\right.$ ed.) Mosby Inc., Sr. Lewis, Missouri, USA, 298 p.
Othman, A. M. S. (2002). Study of the Chemical, Mineralogical and Physiomechanical Properties of Technical Plaster and Local Plaster (Juss). Unpublished M.Sc. thesis, College of Science, University of Mosul, $83 \mathrm{p}$. (in Arabic with English abstract).

Venta, G. J. (1997). Life cycle Analysis of Gypsum Board and Associated Finishing Products. Technical Report, Athena TM Sustainable Materials Institute, Merrickville, Ottawa, Canada, 143 p.

Vogel, I. N. (1961). A Text-book of Quantities Inorganic Analysis ( $3^{\text {rd }}$ ed.). Longman, London, England, 1216 p.

Younis, A. S. T. (2012). Preparation of Dental Stone by Using Local Raw Gypsum and Calcium Chloride Solution. Unpublished M.Sc. thesis, College of Science, University of Mosul, $82 \mathrm{p}$. (in Arabic with English abstract).

Yousif, H. K. (2011). Petrography, Mineralogy and Geochemistry of the Three Types of Gypsum (Nodular, Selenite and Fibrous) in Fat'ha Formation (Middle Miocene) - Northern Iraq. Unpublished M.Sc. thesis, College of Science, University of Mosul, 128 p.

Google Earth Pro V. 7.3.3 7786. (August 24, 2020). Makhmur Area, Iraq. 35 46' 32.4" N, 43 37' 57.3" E. (Accessed August 24, 2020). 
يوخته

يِينج سهميل ز بهريّن جيسوم و ئيّك ز بهريّن جيرى هاتنه كومكرن ز دهفهرا بهرينى ل قره جوغ . يشكنينين كيميايت هاتنهرن بو بهريّن جبسوم بهرى ويشتى كلسكرنى وياقزيا بهريّن جيسوم يِيّن نه كلسكرى و بهريّن جيرى و ماددى") و ميكانيكى هاتنهكرن بو باريس بلاستر ئهوئ ز كلسكرنا سهميلين جيسوم هاتيه دهرئهنجام و لديف به تايبهتمهندييّن عيراقى و ئه مريكى. سهيلهكي جيسوم بورد ز باريس بلاستر هاتهدروستكرن بريّكا

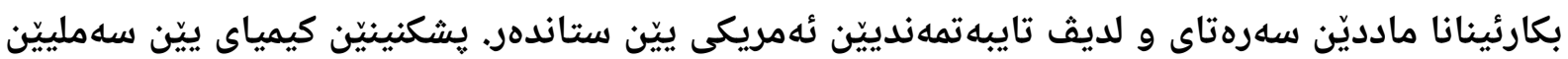
جيسوم ييّن نه كلسكرى و باريس بلاستر وهكى تايبهتمهنديّين عيراقى و ئهمريكى دياربوون ، ههروهسا

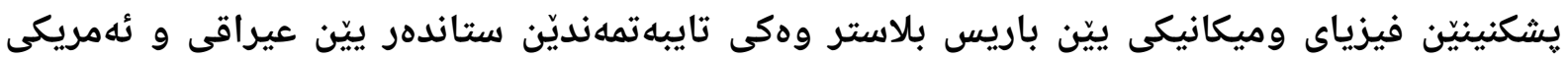
دياربوون. بهريّن جيسوم ئهويّن ل دهثهرا مهخمور ييّن مفانه (باشن) بو دروستكرنا بورديّن ديواري. بيّي

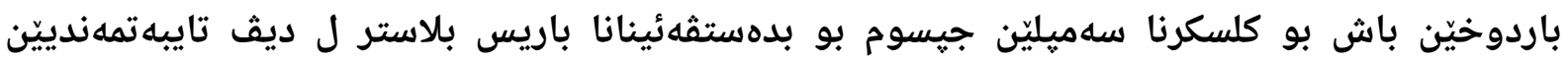

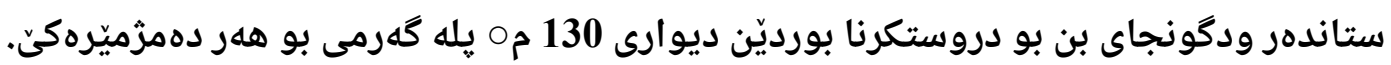
يهيڤِين كليل: جيسوم ، يِيّكهاتا فه تحه، دهثهرا مه خمور، باريس بلاستر، بورديّن ديوارى.

الخلاصة

جمعت خمس عينات من صخور الجبسوم وعينة واحدة من الحجر الجيري من أحد المكاشف الصخرية

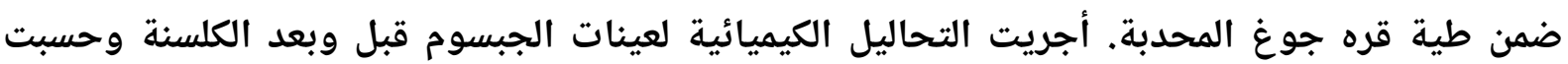

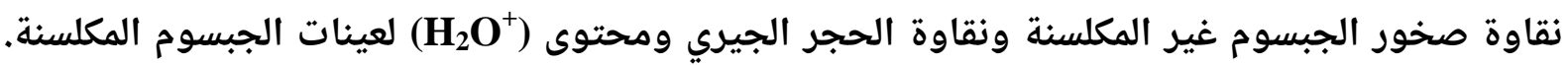
قيست الخواص الفيزيائية والميكانيكية لباريس بلاستر الناتج من كلسنة عينات الجبسوم وحسب ولجبرة المواصفات العراقية والأميركية. حضرت عينة من ألواح الجدار (الجبسوم بورد) من باريس بلاستر باستخدام مواد أساسية وحسب المواصفة القياسية الأميركية. تتوافق التحاليل الكيميائية لعينات الجبسوم غير المكلسنة وباريس بلاستر مع المواصفتين القياسيتين العراقية والأميركية. كما تتوافق ولقيل

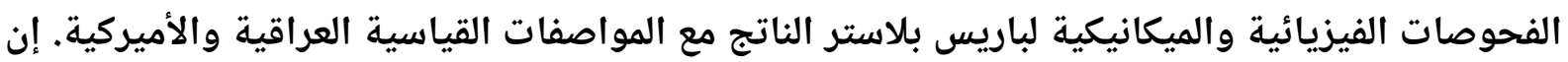
صخور الجبسوم العائدة لتكوين فتحة في منطقة مخمور صالحة لتصنيع ألواح الجدار. إن الظروف المثلى

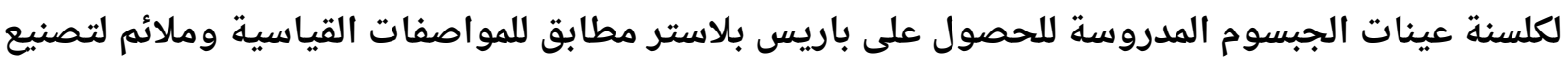
ألواح الجدار هي درجة حرارة 130 م لمدة ساعة واحدة. 